\title{
PENGGUNAAN MOBILE LEARNING BERBASIS HTML-5 PADA PEMBELAJARAN BIOLOGI UNTUK MENINGKATKAN HASIL BELAJAR KOGNITIF DAN KEMANDIRIAN BELAJAR PESERTA DIDIK DI KELAS XI MIPA SEKOLAH MENENGAH ATAS
}

\author{
Euis Durriyah ${ }^{1}$, Dudi Suprihadi ${ }^{2}$ \\ 1,2Institut Pendidikan Indonesia (IPI) Garut \\ Email : 1euisdury@gmail.com, 20udisuprihadi@gmail.com
}

\begin{abstract}
ABSTRAK
Penelitian ini bertujuan untuk mengetahui penggunaan mobile learning berbasis html-5 pada pembelajaran biologi untuk meningkatkan hasil belajar kognitif dan kemandirian belajar peserta didik di kelas XI MIPA Sekolah Menengah Atas. Metode penelitian yang digunakan adalah metode penelitian eksperimen dalam bentuk desain quasi eksperimen. Sampel penelitian ini adalah kelas XI MIPA SMAN 15 Garut. Hasil Penelitian ini menyimpulkan bahwa peningkatan hasil belajar kognitif kelas eksperimen yaitu kelas yang dalam proses pembelajarannya menggunakan mobile learning berbasis Html-5 sebagian besar mengalami peningkatan tergolong tinggi, yaitu sebanyak 63\%, mengalami peningkatan kategori sedang sebanyak $37 \%$. Sedangkan peningkatan hasil belajar kognitif kelas kontrol sebagian besar mengalami peningkatan tergolong sedang, yaitu sebanyak $70 \%$, mengalami peningkatan kategori tinggi sebanyak $24 \%$, dan peserta didik yang mengalami peningkatan yang rendah sebanyak $6 \%$. Untuk kemandirian belajar, peningkatan kemandirian belajar peserta didik kelas eksperimen yaitu yang dalam proses pembelajarannya menggunakan mobile learning berbasis $\mathrm{Html}$ 5 , umumnya masih mengalami peningkatan yang rendah sebanyak $69 \%$, dan $31 \%$ mengalami peningkatan tergolong sedang, serta tidak ada yang mengalami peningkatan yang tergolong tinggi. Sedangkan peningkatan kemandirian belajar kelas kontrol yaitu yang dalam proses pembelajarannya tidak menggunakan mobile learning berbasis Html-5, umumnya masih mengalami peningkatan yang rendah sebanyak $97 \%$, dan $3 \%$ mengalami peningkatan tergolong sedang.
\end{abstract}

Kata Kunci : Mobile Learning , Html-5,Hasil belajar kognitif ,Kemandirian Belajar,

\begin{abstract}
This study studies learning using html-5-based mobile learning in biology learning to improve cognitive learning outcomes and learner learning independence in class XI MIPA High School. The research method used is a research method in the form of a quasi-experimental design. The sample of this study was class XI MIPA SMAN 15 Garut. The results of this study discuss the increase in cognitive learning outcomes of the experimental class which is the class that in the learning process using Html-5 based mobile learning mostly increases the increase classified as high, which is as much as $63 \%$, increasing the category increased by $37 \%$. While increasing learning outcomes increase control increased by $70 \%$, increased by $70 \%$, increased the high category by $24 \%$, and students increased by $6 \%$. For learning independence, the increase in learning independence of experimental class students is that in the learning process using Html-5-based mobile learning, participation still increases low spending by $69 \%$, and $31 \%$ is increased. high. While increasing the independence of control class learning in the learning process does not use Html-5 based mobile learning, some still increase low efficiency by $97 \%$, and $3 \%$ increase the increase is classified as moderate.
\end{abstract}

Keywords: Mobile Learning, Html-5, Cognitive Learning Outcomes, Self-Regulated Learning 


\section{A. PENDAHULUAN}

Dinamika global yang semakin pesat dengan hadirnya era Industri 4.0 merupakan tantangan tersendiri bagi dunia pendidikan. Oleh karena itu dunia pendidikan harus menyesuaikan dengan tantangan era industri 4.0. Pendidikan di era industri 4.0 ini harus memanfaatkan teknologi digital dalam proses pembelajaran sesuai dengan era industri 4.0 yang berbasis sistem siber (Cyber Pyshical System), dengan mengabungkan antara teknologi digital dan fisik.

Dari sejumlah perubahan yang harus dilakukan, perbaikan sumber daya manusia adalah salah satu hal yang harus sangat diperhatikan. Guru sebagai ujung tombak pendidikan perlu untuk selalu mengikuti perkembangan Teknologi Informasi dan Komunikasi (TIK) dan menerapkannya dalam proses pembelajaran. Guru tidak punya alasan lagi untuk menghindar atau mengelak perkembangan teknologi yang pesat ini. Pesatnya perkembangan TIK ini , memberikan banyak hal positif karena mampu memberikan dukungan sarana dan prasarana yang lebih canggih, lebih memudahkan, efektif dan efisien bagi pemecahan masalah- masalah pembelajaran.

Menurut Surya (2016:170) bahwa "Teknologi memiliki potensi untuk memberikan sejumlah peluang pembelajaran bagi siswa dan memperluas fungsi-fungsi kognitif'. Peserta didik harus memiliki keterampilan yang memadai dalam menggunakan berbagai bentuk dan jenis teknologi informasi dan komunkasi dalam mendapatkan informasi.

Berdasarkan pengalaman peneliti pada proses pembelajaran, secara khusus kendala yang dihadapi yaitu kurangnya konsentrasi peserta didik dalam proses pembelajaran akibat penggunaan smartphone yang tidak tepat waktu dan tempat yakni saat proses pembelajaran tatap muka berlangsung. , sehingga berpengaruh terhadap hasil belajar dan kemandirian belajar peserta didik. Smartphone yang dimiliki sebagian besar hanya digunakan untuk hiburan atau sarana media social. Oleh karena itu penggunaan Smartphone atau gadget yang sebagian besar dimiliki peserta didik menginspirasi peneliti untuk dapat lebih meningkatkan nilai manfaatnya dalam hal ini untuk pembelajaran Biologi dengan mobile learning. Di dalam gadget peserta didik ini, peneliti memfasilitasi peserta didik untuk memanfaatkan konten-konten pembelajaran yang tersedia yang berkaitan dengan materi pembelajaran untuk meningkatkan hasil belajar dan kemandirian belajar biologi peserta didik.

Rumusan Masalah dalam penelitian ini adalah "Apakah Penggunaan Mobile Learning Berbasis Html-5 Pada Pembelajaran Biologi dapat Meningkatkan Hasil Belajar Kognitif dan Kemandirian Belajar Peserta Didik? Sedangkan tujuan secara umum dalam penelitian ini adalah mengetahui penggunaan Mobile Learning Berbasis Html-5 pada pembelajaran biologi untuk Meningkatkan Hasil Belajar Kognitif dan Kemandirian Belajar Peserta Didik. Manfaat penelitian penggunaan Mobile Learning Berbasis Html-5ini dapat meningkatkan hasil belajar kognitif, dan kemandirian belajar dan kemampuan literasi digital dalam pembelajaran biologi, dapat dijadikan media alternatif dalam melakukan pembelajaran inovatif dan berpusat pada peserta didik sesuai dengan tuntutan kurikulum 2013.

\section{B. Tinjauan Literatur}

\section{Mobile Learning}

Mobile Learning atau dikenal dengan M-Learning merupakan bagian dari E-Learning, adalah model pembelajaran modern yang memanfaatkan teknologi informasi dan komunikasi. 
Sistem M-Learning ini memanfaatkan mobilitas dari perangkat mobile dintaranya smartphone. Daryanto (,2013:31) E learning secara harfiah merupakan akronim dari E dan Learning. E bermakna electronik dan Learning berarti proses belajar. Jadi E-learning adalah system pembelajaran secara elektronik, menggunakan media elektronik, interenet, komputer dan file multimedia (suara, gambar, animasi dan video). Mobile Learning menurut Darmawan (2017:15) adalah salah satu alternatif layanan pembelajaran harus dilaksanakan dimana pun dan kapan pun. Pemikiran dalam mengembangkan mobile learning didasari oleh alasan alasan pokok, yaitu : dapat digunakan kapanpun dimanapun (dalam jaringan maupun luar jaringan), cakupan luas, dapat menggunakan jaringan seluler komersil tanpa harus membangun sendiri karena jaringan sudah tersedia di manamana, integrasi dengan system yang ada misalnya integrasi dengan e-learning, integrasi dengan sistem pembelajaran, dll.

Darmawan (2014:170) menjelaskan bahwa $M$ Learning pada dasarnya ada dalam dua versi yaitu offline dan online. Versi offline dilakukan hanya satu kali install, tidak terkoneksi server (stand alone) Sedangkan versi online memiliki karakteristik dalam memulai pembelajaran dengan cara : 1) hanya menginstall engine, 2) dapat diupdate dengan menghubungakan ke server.3)dapat berinteraksi dengan pembelajar atau pengajar (diskusi/Tanya jawab). Dalam system pembelajaran berbasis komputer seperti mobile learning ini, maka langkah awal yang harus dikembangkan dalam memproduksinya adalah mendesain model alur berpikir program tersebut atau dikenal dengan Flow Chart yang komunikatif.

\section{Hasil Belajar Kognitif}

Secara psikologis (Surya, 2015: 111) pembelajaran adalah suatu proses yang dilakukan oleh individu untuk memperoleh suatu perubahan perilaku secara menyeluruh, sebagai hasil dari interaksi individu itu dengan lingkungannya.
Hasil proses pembelajaran menurut Surya(2015:119) ialah “...perubahan perilaku individu". Perilaku hasil pembelajaran secara keseluruhan mencakup aspek kognitif, konatif, afektif dan motorik. Salah satu pakar yang banyak memberikan kontribusi berkenaan dengan hasil pembelajaran adalah Benyamin Bloom yang dikenal dengan sebutan Taksonomi tujuan pendidikan Bloom yang menyebutkan ada tiga ranah perilaku sebagai tujuan dan hasil pembelajaran, yaitu 1) kognitif, 2) afektif,3) psikomotor.

Menurut Abdurahman (dalam Jihad dan Haris, 2013:14-15) 'Hasil belajar adalah kemampuan yang diperoleh anak setelah melalui kegiatan belajar'. Menurut pendapat Juliah (dalam Jihad dan Haris, 2013:14-15), 'hasil belajar adalah segala sesuatu yang menjadi milik siswa sebagai akibat dari kegiatan belajar yang dilakukannya'.

\section{Kemandirian Belajar}

"Konsep belajar mandiri (individualize learning) adalah pengaturan program belajar yang diorganisasikan sedemikian rupa sehingga setiap peserta didik dapat memilih dan atau menentukan bahan dan kemandirian belajar sendiri."(Abdulhak dan Darmawan, 2013: 121). Sistem belajar mandiri sebagai suatu sistem dapat dipandang sebagai struktur yaitu suatu susunan dengan hirarki tertentu, sebagai , proses yaitu adanya tata cara atau prosedur yang runut dan sebagai produk yaitu dengan adanya hasil atau wujud yanag bermanfaat.

Sumarmo, ( 2014:1). Kemandirian belajar sebagai terjemahan dari istilah selfregulated learning atau disingkat SRL mengemukakan bahwa SRL atau kemandirian belajar merupakan proses perancangan dan pemantauan diri yang seksama terhadap proses kognitif dan afektif dalam menyelesaikan suatu tugas akademik. Lebih lanjut dikemukakan bahwa kemandirian belajar bukan merupakan bakat, tetapi merupakan hasil belajar yang dapat dikembangkan melalui pembelajaran yang relevan. Bandura (Sumarmo, 2014: 2) mendefinisikan kemandirian belajar sebagai kemampuan memantau perilaku sendiri, dan merupakan kerja-keras personaliti manusia. 


\section{Metodologi Penelitian}

Pendekatan yang digunakan dalam penelitian ini adalah pendekatan kuantitatif dengan metode eksperimen bentuk quasi experimental, yaitu desain yang mempunyai kelompok kontrol tetapi tidak dapat berfungsi sepenuhnya untuk mengontrol variabel-variabel luar yang memengaruhi pelaksanaan eksperimen (Sugiyono, 2013: 114). Desain penelitian menghubungkan antara variabel $X$ dan variabel Y. Keterkaitan antara keduanya digambarkan pada Tabel berikut ini :

\section{Tabel 3.1}

\begin{tabular}{lccc}
\hline Kelompok & Pre test & Perlakuan & Post test \\
\hline Eksperimen & $\mathrm{O}$ & $\mathrm{X}$ & $\mathrm{O}$ \\
Kontrol & $\mathrm{O}$ & & $\mathrm{O}$ \\
\hline
\end{tabular}

Menurut Darmawan (2016:137) "Populasi adalah sumber data dalam penelitian tertentu yang memiliki jumlah banyak dan luas." Berdasarkaan pengertian tersebut, maka peneliti menentukan populasi dalam penelitian ini adalah seluruh peserta didik di SMAN 15 Garut kelas XI MIPA Tahun Pembelajaran 2019/2020 sebanyak 8 kelas yaitu kelas XI MIPA-1 sampai dengan X MIPA-8 . Sampel yang diambil dari delapan kelas XI MIPA adalah satu kelas (XI MIPA-6) untuk dijadikan kelas eksperimen, dan kelas (XI MIPA-5) dijadikan sebagai kelas kontrol. Lokasi penelitian ini dilakukan di SMA Negeri 15 Garut yang berada di Jl. Panawuan No. 3A , Desa Sukajaya Kecamatan Tarogong Kidul Kabupaten Garut.

\section{HASIL DAN PEMBAHASAN}

Hasil penelitian untuk hasil belajar kognitif diperoleh dari data skor hasil tes awal dan tes akhir peserta didik pada kelompok eksperimen dan kelompok kontrol yang terlihat pada table 4.1 dan 4.2
Tabel 4.1

Rekap Rata-rata Kemampuan Kognitif Sebelum, Sesudah dan Peningkatan Hasil Belajar Kognitif Kelas Eksperimen

\begin{tabular}{ccc}
\hline Hasil & $\begin{array}{c}\text { Rata-rata } \\
\text { nilai }\end{array}$ & Kriteria \\
\hline Tes Awal & 24,80 & Tidak Tuntas \\
Tes Akhir & 78,51 & Tuntas \\
Peningkatan & 0,71 & Tinggi \\
\hline
\end{tabular}

Dilihat dari nilai rata-rata seperti pada tabel 4.1 tersebut, menunjukkkan bahwa nilai ratarata sebelum pembelajaran (tes awal) adalah 24,80 masih belum mencapai nilai KKM yaitu 67 jadi belum tuntas, sedangkan nilai rata-rata sesudah pembelajaran dengan Mobile Learning Berbasis Html-5 adalah 78,51 lebih dari KKM yang artinya sudah tuntas. Rata rata peningkatannya rata 0,71 termasuk katagori tinggi. mengalami peningkatan yang rendah sebanyak $6 \%$. Sedangkan hasil rata rata untuk kelompok kontrol dapat dilihat dari tabel di bawah ini .

Tabel 4.2

Rekap Rata-rata Kemampuan Kognitif Sebelum, Sesudah, dan Peningkatan Hasil Belajar Kognitif Kelas Kontrol

\begin{tabular}{ccc}
\hline Hasil & $\begin{array}{c}\text { Rata-rata } \\
\text { nilai }\end{array}$ & Kriteria \\
\hline Tes Awal & 26,55 & Tidak Tuntas \\
Tes Akhir & 70,55 & Tuntas \\
Peningkatan & 0,60 & Sedang \\
\hline
\end{tabular}

Dilihat dari nilai rata-rata seperti pada tabel 4.2 tersebut, menunjukkkan bahwa nilai rata-rata sebelum pembelajaran (tes awal)adalah 26,55 masih belum mencapai nilai KKM yaitu 67 jadi belum tuntas, sedangkan nilai rata-rata sesudah pembelajaran adalah 70,55 lebih dari KKM yang artinya sudah tuntas. Rata rata peningkatan pada kelas kontrol adalah 0,60 termasuk kategori sedang 
yaitu $80,83 \%$. Peningkatan hasil belajar kognitifnya dihitung dengan menggunakan gain ternormalisasi. Skor hasil belajar kognitif tersebut, penulis sajikan pada tabel berikut:

Tabel 4.3

Kemampuan Kognitif Sebelum, Sesudah, dan Peningkatan Hasil Belajar Kognitif Peserta Didik

\begin{tabular}{|c|c|c|c|c|c|c|c|c|c|c|}
\hline \multirow{2}{*}{ Kelas } & \multirow{2}{*}{$\begin{array}{l}\text { Skor } \\
\text { Ideal }\end{array}$} & \multicolumn{3}{|c|}{ Sebelum Pembelajaran } & \multicolumn{3}{|c|}{ Setelah Pembelajaran } & \multicolumn{3}{|c|}{$\begin{array}{c}\text { Peningkatan Hasil Belajar } \\
\text { Kognitif }\end{array}$} \\
\hline & & $x_{\min }$ & $x_{\max }$ & $\bar{x}$ & $x_{\text {min }}$ & $x_{\max }$ & $\bar{x}$ & $x_{\min }$ & $x_{\max }$ & $\bar{x}$ \\
\hline Eksperimen & 35 & 2 & 10 & 6,20 & 13 & 23 & 19,63 & 0,35 & 0,91 & 0,71 \\
\hline Kontrol & 33 & 4 & 11 & 6,64 & 11 & 22 & 17,64 & 0,22 & 0,81 & 0,60 \\
\hline
\end{tabular}

Dari tabel 4.3 tersebut, tampak bahwa hasil belajar kognitif pada kedua kelas, baik pada sebelum, sesudah dilakukannya pembelajaran, serta peningkatan hasil belajar kognitif berbeda. Perbedaan peningkatan hasil belajar kognitif secara signifikan dari data tersebut, dilakukan dengan pengujian hipotesis.

Hasil pengujian hipotesis tersebut, peneliti sajikan pada tabel berikut:

Tabel 4.4

Uji Perbedaan Hasil belajar kognitif Sebelum Dilakukan Pembelajaran

\begin{tabular}{lcccccc}
\hline Kelas & $\mathrm{n}$ & Mean Rank & $\mathrm{U}$ & $\mathrm{z}$ & Sig. & Kesimpulan \\
\hline Eksperimen & 35 & 43,30 & 269,5 & $-3,782$ & 0,000 & Terima Ha \\
Kontrol & 33 & 25,17 & & & & \\
\hline
\end{tabular}

peningkatan hasil belajar kognitif antara peserta didik yang menggunakan Mobile Learning Berbasis Html-5 dengan peserta didik yang tidak menggunakan Mobile Learning Berbasis Html-5.”. Oleh karena itu hipotesis satu penelitian ini diterima.

Hasil penelitian untuk Kemandirian Belajar diperoleh dari data skor hasil angket sebelum dan sesudah pembelajaran peserta didik pada kelompok eksperimen dan kelompok kontrol yang terlihat pada table berikut ini.

Tabel 4.5

Rekap Hasil Kemandirian Belajar Kelas Eksperimen

\begin{tabular}{lcccccc}
\hline & \multicolumn{2}{c}{ Awal } & \multicolumn{2}{c}{ Akhir } & \multicolumn{2}{c}{ Peningkatan } \\
Kemandirian & & & & & & \\
& fi & $(\%)$ & Fi & $(\%)$ & fi & $(\%)$ \\
\hline Rendah & 1 & 3 & 0 & 0 & 24 & 69 \\
Sedang & 31 & 89 & 15 & 43 & 11 & 31 \\
Tinggi & 3 & 9 & 20 & 57 & 0 & 0 \\
\hline Jumlah & 35 & 100 & 35 & 100 & 35 & 100 \\
\hline
\end{tabular}

Tabel 4. 6

Rekap Hasil Angket Kemadirian Belajar Kelas Kontrol
Dari hasil pengujian tersebut, pada Tabel 4.4, diperoleh informasi bahwa kelas eksperimen, mempunyai nilai rata-rata rank sebesar 43,30; sedangkan untuk kelas kontrol, mempunyai rata-rata rank sebesar 25,17. Kemudian nilai Mann-Whitney sebesar 269,5 dengan z sebesar -3,782 dan nilai Asymp. Sig. (2-tailed) sebesar 0,000. Adapun kriteria pengujian hipotesis adalah jika nilai Asymp.Sig. (2-tailed) lebih besar dari $\alpha$, maka Ho diterima. Karena nilai Asymp. Sig. (2-tailed) lebih kecil dari $\alpha$, maka hasil pengujian tersebut menerima Ha dan menolak Ho, sehingga dapat disimpulkan bahwa: "Terdapat perbedaan

\begin{tabular}{lcccccc}
\hline Kelas & $\mathrm{n}$ & Mean Rank & $\mathrm{U}$ & $\mathrm{z}$ & Sig. & Kesimpulan \\
\hline Eksperimen & 35 & 47,84 & 110,5 & $-5,736$ & 0,000 & Terima Ha \\
Kontrol & 33 & 20,35 & & & & \\
\hline
\end{tabular}


Dari Tabel 4.5 dan tabel 4,6, diketahui bahwa pada kemandirian belajar peserta didik kelas eksperimen pada awal pembelajar pada umumnya tergolong kategori sedang yaitu sebanyak $89 \%$. Setelah pembelajaran dengan mobile learning dilakukan, maka peserta didik memiliki kemandirian belajar lebih dari setengahnya tergolong tinggi. Namun dilihat dari peningkatan kemandirian belajar, umumnya masih mengalami peningkatan yang rendah sebanyak $69 \%$, dan $31 \%$ mengalami peningkatan tergolong sedang, serta tidak ada yang mengalami peningkatan yang tergolong tinggi. Sedangkan pada kemandirian belajar peserta didik kelas kontrol pada awal pembelajaran pada umumnya tergolong kategori sedang yaitu sebanyak $91 \%$, hanya sebanyak $9 \%$ yang memiliki kemandirian belajar tergolong tinggi. Setelah pembelajaran dilakukan, peserta didik pada umumnya masih memiliki kemandirian belajar tergolong sedang, namun peserta didik yang kemandirian belajarnya tergolong tinggi mengalami peningkatan menjadi 24\%. Namun dilihat dari peningkatan kemandirian belajar, umumnya masih mengalami peningkatan yang rendah sebanyak 97\%, dan 3\% mengalami peningkatan tergolong sedang, serta tidak ada yang mengalami peningkatan yang tergolong tinggi.

Hasil obesrvasi kemandirian selama proses pembelajaran pada pertemuan pertama sudah menunjukkan adanya kemandirian $79,17 \%$. Kegiatan peserta didik selama proses pembelajaran dengan mobile learning berbasis HTML-5 diamati secara keseluruhan, dimulai dari masuk kelas sampai akhir pembelajaran. Pertemuan kedua kemandirian peserta didik meningkat mencapai $89,17 \%$. Hasil obesrvasi kemandirian kelompok kontrol selama proses pembelajaran pada pertemuan pertama sudah menunjukkan adanya kemandirian 70,00\%. Kegiatan peserta didik selama proses pembelajaran tanpa mobile learning berbasis HTML-5 diamati secara keseluruhan, dimulai dari masuk kelas sampai akhir pembelajaran. Pertemuan kedua kemandirian peserta didik meningkat mencapai menjadi $80,83 \%$

Tabel 4.7

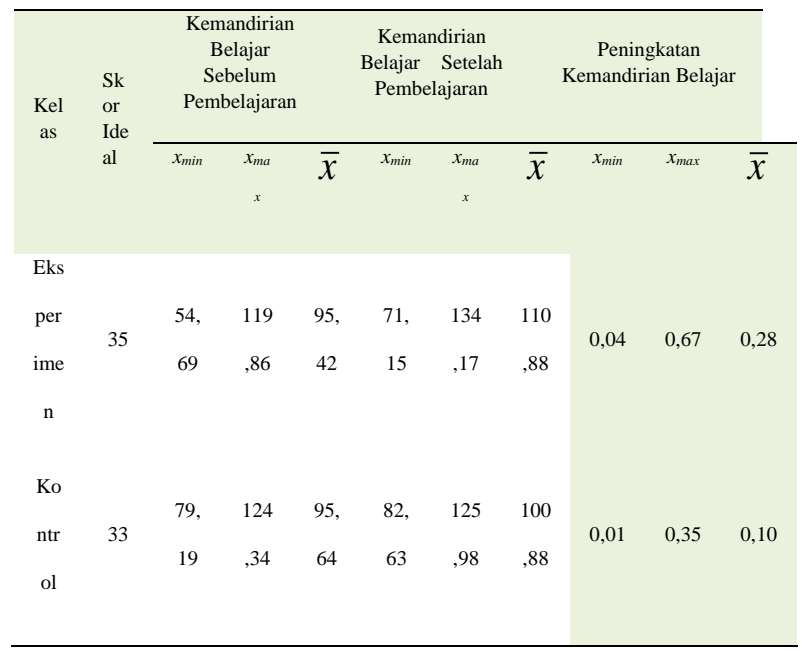

Kemandirian belajar peserta didik

Dari tabel 4.7 tersebut, tampak bahwa kemandirian belajar pada kedua kelas, baik pada sebelum, sesudah dilakukannya pembelajaran, serta peningkatan kemandirian belajar berbeda. Perbedaan peningkatan kemandirian belajar secara signifikan dari data tersebut, diketahui dari hasil pengujian hipotesis. Pengujian hipotesis untuk uji perbedaan peningkatan hasil belajar kognitif, penulis paparkan

\begin{tabular}{lcccccc}
\hline & \multicolumn{2}{c}{ Awal } & \multicolumn{2}{c}{ Akhir } & \multicolumn{2}{c}{ Peningkatan } \\
Kemandirian & & & & & & \\
& & & & & & \\
& fi & $(\%)$ & fi & $(\%)$ & fi & $(\%)$ \\
\hline Rendah & 0 & 0 & 0 & 0 & 32 & 97 \\
Sedang & 30 & 91 & 25 & 76 & 1 & 3 \\
Tinggi & 3 & 9 & 8 & 24 & 0 & 0 \\
Jumlah & 33 & 100 & 33 & 100 & 33 & 100
\end{tabular}

sebagai berikut. 
Tabel 4.8

Uji Perbedaan Kemandirian belajar Setelah Dilakukan Pembelajaran

Dari hasil pengujian seperti tersaji pada Tabel 4.8, diperoleh informasi kelas eksperimen mempunyai nilai rata-rata rank sebesar 20,35. Kemudian nilai MannWhitney sebesar 110,5 dengan z sebesar 5,736 dan nilai Asymp. Sig. (2-tailed) sebesar 0,000. Adapun kriteria pengujian hipotesis adalah jika nilai Asymp.Sig. (2tailed) lebih besar dari $\alpha$, maka Ho diterima. Karena nilai Asymp. Sig. (2tailed) lebih kecil dari $\alpha$, maka hasil pengujian tersebut menerima $\mathrm{Ha}$ dan menolak Ho, sehingga dapat disimpulkan bahwa: "Terdapat perbedaan peningkatan kemandirian belajar peserta antara peserta didik yang menggunakan Mobile Learning Berbasis Html-5 dengan peserta didik yang tidak menggunakan Mobile Learning Berbasis Html-5". Oleh karena itu hipotesis dua penelitian ini diterima.

Kemudian dari perbandingan hasil observasi kemandirian belajar peserta didik yang menggunakan mobile learning berbasis HTML-5 dengan yang tidak menggunakan mobile learning berbasis HTML-5 tampak pada diagram berikut ini :

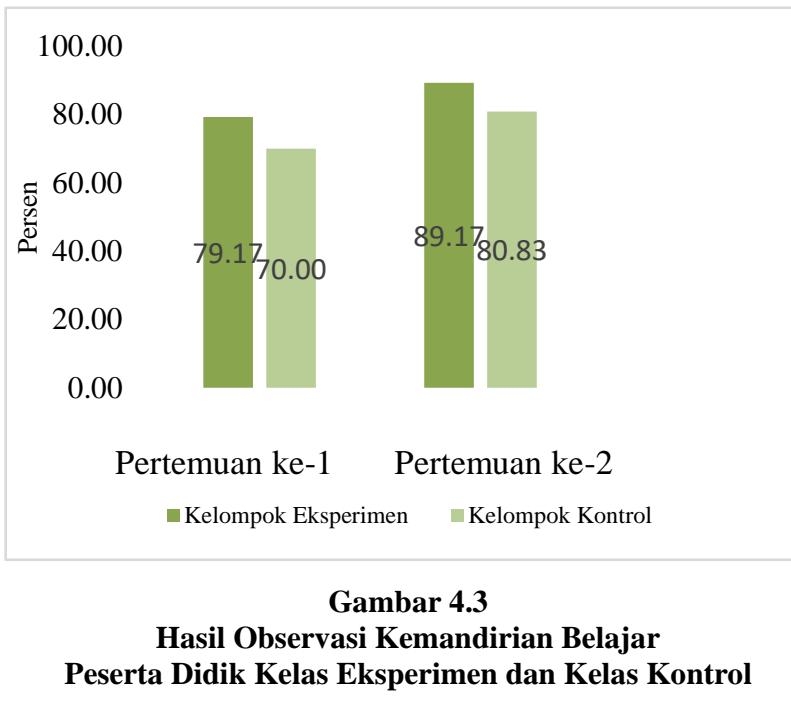

Dari diagram di atas tampak bahwa kemandirian belajar peserta didik hasil observasi selama pembelajaran baik pada kelompok eksperimen maupun kelompok kontrol sudah menunjukkan kemandirian belajar sejak pertemuan pertama proses pembelajaran. Kemandirian belajar peserta didik kelompok eksperimen pada pertemuan pertama yaitu $79,17 \%$ lebh tinggi dibandingkan dengan kemandirian belajar pada kelompok kontrol yaitu $70,00 \%$. Demikian pula hasil observasi pada proses pembelajaran pertemuan kedua terdapat peningkatan dari kedua kelompok. Kemandirian belajar peserta didik kelompok eksperimen pada pertemuan kedua yaitu $89,17 \%$ lebh tinggi dibandingkan dengan kemandirian belajar pada kelompok kontrol yaitu $80,83 \%$.

Dari hasil di atas maka dapat dianalisis ahwa Pakar yang memberikan kontribusi bagi perkembangan kognitif adalah Jean Piaget. Menurut Piaget ( Surya, 2015: 144) bahwa' kognitif merupakan hasil dari pembentukan adaptasi biologi. Perkembangan kognitif terbentuk melalui interaksi antara individu dengan lingkungan melalui dua proses, yaitu organisasi dan adaptasi. 'Berkaitan dengan uraian tersebut Darmawan (2016:52), mengemukakan bahwa“ pembelajaran $e$ leaning memungkinkan terjadinya proses asimilasi dan akomodasi secara simultan". Pembelajaran e-learning memberi keleluasaan bagi peserta didik untuk melakukan penyerapan materi ajar pada waktu yang dianggap paling tepat oleh peserta didik. Hal ini mendukung pembelajaran mobile learning yang merupakan bagian dari pembelajran $e$ learning.

Konten materi pembelajaran biologi tentang system saraf pada mobile learning dirancang agar terjadi proses organisasi dan adaptasi sebagaimana pengertian yang diuraikan di atas. Peserta didik pada kelompok eksperimen diberi pengalaman belajar dalam hal ini lingkungan yang mendukung pembelajaran system saraf dengan menggunakan mobile learning 
berbasis Html-5, agar dikenal sebagai pengalaman baru yang memberikan kesempatan peserta didik untuk melakukan proses-proses kognisi dalam dirinya, seperti yang diungkapkan oleh Surya (2016; 2) "kognisi mempunyai makna sebagai suatu proses pengenalan terhadap segala sesuatu yang berada di lingkungan individu dan menjadikannya sesuatu yang tidak terpisahkan dari keseluruhan perilaku individu dalam seluruh proses kehidupannya".

Berdasarkan teori kontruktivisme (Darmawan, 2016:51) bahwa "pengetahuan adalah hasil kontruksi manusia. Manusia mengkontruksi pengetahuannya melalui interaksi dengan objek, fenomena, pengalaman dan lingkungan mereka. Oleh karena itu, pengetahuan tidak dapat begitu saja ditransfer oleh guru kepada peserta didiknya, tetapi peserta didik membangun sendiri pengetahuannya dari lingkungan sebagai pengalaman belajarnya. Piaget (Suparno, 1997), mengemukakan bahwa pembelajar dalam segala usia secara aktif terlibat dalam proses perolehan informasi dan membangun pengetahuan mereka sendiri.

Dari hasil penelitian diketahui bahwa hasil belajar kognitif peserta didik tentang materi system saraf pada kelompok eksperimen, sebagian besar sudah tuntas, yaitu sebanyak $89 \%$, tetapi masih ada sebanyak $11 \%$ yang belum tuntas. Sedangkan peningkatan hasil belajar kognitif kelas eksperimen sebagian besar mengalami peningkatan tergolong tinggi, yaitu sebanyak $63 \%$, peningkatan kategori sedang sebanyak $37 \%$, dan tidak ada yang mengalami peningkatan yang rendah. Hal ini dimungkinkan karena penggunaaan mobile learning berbasis Html-5 memberikan peluang lebih besar untuk mengoptimalkan fungsi-fungsi kognitif peserta didik. Dengan mobile learning berbasis $\mathrm{Html}-5$ peserta didik lebih sering melakukan pengamatan ,penyimpanan informasi lebih mudah, mempunyai proses berpikir lebih banyak karena dapat menggunakan konten pembelajaran system saraf kapanpun dan dimanapun. Video video pembelajaran yang terdapat dalam konten mobile learning yang disajikan misalnya video tentang jalannya impuls pada saat gerak biasa dan gerak reflek dapat diputar ulang lebih sering oleh peserta didik sehingga dapat lebih memahami. Mekanisme penghantaran impuls yang abstak dapat lebih dipahami melalui video. Video menyediakan sumber daya yang kaya dan hidup bagi aplikasi multimedia termasuk pada mobile learning. Animasi yang disajikan diawal materi mobile learning merupakan apersepsi agar lebih menarik perhatian peserta didik. Komposisi warna, yang digunakan, keterbacaan teks, jenis huruf, karakter huruf mudah dipahami, keseimbangan tata letak antara gambar dengan teks lebih jelas, ketersediaan petunjuk, kejelasan uraian materi dan memuat kesimpulan dari materi system saraf sebagai konten mobile learning berkontribusi juga untuk meningkatkan hasil belajar kognitif peserta didik karena termotivasi untuk lenih sering membuka mobile learning pada smarphonenya. Hal ini sesuai dengan yang dikemukakan Surya (2016:170) bahwa "Teknologi memiliki potensi untuk memberikan sejumlah peluang pembelajaran bagi siswa dan memperluas fungsi-fungsi kognitif'. Peran media dalam hal ini adalah mobile learning mempengaruhi perkembangan kognitif peserta didik. Peserta didik lebih antusias untuk sering membuka dan mempelajari konten materi pada mobile learning dan bertanya apabila ada materi yang kurang jelas atau kurang dipahami.

Sedangkan pembelajaran pada kelompok kontrol pembelajaran dilakukan sebagai mana biasa pembelajaran sehari- hari sesuai dengan kurikulum 2013. Pembelajaran sistem saraf menggunakan media power point yang konten materi pembelajarannya hampir sama dengan konten materi mobile learning. Jadi 
pembelajaran pada kelas kontrol pun memberikan kesempatan peserta didik untuk melakukan proses-proses kognisi, proses organisasi dan adaptasi sebagaimana juga yang terjadi pada kelas eksperimen. Hanya pada kelas ini masih banyak dominasi guru, karena guru masih memberikan penjelasan lebih banyak kepada peserta didik dengan menggunakan media power point. Peserta didik memperhatikan dengan sungguh sungguh tentang materi sistem saraf yang dijelaskan oleh guru. Peserta didik membangun pengetahuannya dengan melakukan pemrosesan informasi dari penjelasan guru. Peserta didik kurang diberi kesempatan yang lebih luas untuk membangun pengetahuannya Pada kelompok kontrol menunjukkan bahwa secara umum hasil belajar kognitif pembelajaran biologi materi sistem saraf kebanyakan sudah tuntas diketahui bahwa pada hasil belajar kognitif kelas kontrol sebagian besar sudah tuntas, yaitu sebanyak $76 \%$, namun masih ada sebanyak $24 \%$ belum tuntas. Kemudian peningkatan hasil belajar kontrol sebagian besar mengalami peningkatan tergolong rendah $6 \%$, peningkatan katagori sedang yaitu sebanyak $70 \%$, mengalami peningkatan kategori tinggi sebanyak $24 \%$. Hasil belajar kognitif pada kelompok kontrol yang mengalami peningkatkan, ini menunjukkan bahwa proses pembelajaran sistem saraf dengan pembelajaran biasa memberikan kontribusi yang positif. Penggunaan media power point yang digunakan pada pembelajaran kelompok kontrol juga telah memberi kesempatan kepada peserta didik untuk mengembangkan fungsi-fungsi kognitifnya. Peserta didik mendapat kesempatan untuk bertanya kepada guru, berdiskusi dengan peserta didik lain, melakukan pemrosesaan informasi dari konsep system saraf yang dibahas. Fungsi media yang digunakan pada proses pembelajaran ini terpenuhi. Sebagaimana yang diungkapkan Levied an Lantz (Arsyad : 2016:20) bahwa salah satu fungsi media pembelajaran adalah fungsi kognitif, bahwa lambang visual atau gambar memperlancar pencapaian tujuan untuk memahami dan mengingat informasi atau pesan yang terkandung dalam gambar. Sajian teks, gambar, video tentang system saraf terdapat dalam media power point.

Dari hasil uji hipotesis dengan taraf kepercayaan $5 \%$ menyatakan bahwa: "Terdapat perbedaan peningkatan hasil belajar kognitif, antara kelas eksperimen dan kelas kontrol". Sehingga dapat dikatakan peningkatan hasil belajar kognitif, kelas eksperimen lebih baik dari kelompok Kontrol .

Walaupun pada kelompok kontrol mengalami peningkatan hasil belajar kognitif, tetapi dari hasil uji hipotesis terdapat perbedaan peningkatan dengan kelompok eksperimen. Hal ini dapat terjadi karena ada faktor yang membedakan dengan kelompok eksperimen yaitu adanya penggunaan media mobile learning berbasis Html-5. Konten materi sistem saraf yang disajikan pada kedua kelompok sampel sama. Perbedaannya terletak pada fasilitas berupa media mobile learning berbasis Html-5 memberi kesempatan peserta didik intuk lebih banyak berinteraksi dan mengulang pembahsan materi yang sangat terbatas di ruang kelas. Konten mobile learning yang berua teks , gambar dan video yang dapat diakses sesering memungkin membrikan kontribusi positif terhadap peningkatah hasil belajar kognitif kelompok eksperimen. Sedangkan pembelajaran biasa yang menggunakan media power point akses untuk melakukan pengulangan dan penguatan terhadap materi system saraf terbatas hanya di ruang kelas. Kedua-keduanya dalam pembelajaran menggunakan media, tetapi pada kelompok kontrol media yang digunakan adalah media power point yang sudah biasa digunakan dalam proses pembelajan biasa. Media itu digunakan tidak interaktif dan akses untuk menikmati media tersebut hanya terjadi di dalam ruang kelas pada saat tatap muka. Secara 
umum fungsi media pada kedua kelompok sampel dapat terpenuhi, seperti yang diungkapkan oleh Levied an Lantz (Arsyad : 2016:20) yang mengemukakan empat fungsi media pembelajaran, itu karena media pembelajaran khususnya media visual memiliki empat fungsi yaitu fungsi atensi , afektif, kognitif dan fungsi kompensaris.

Pada kelompok eksperimen media yang digunakan adalah mobile learning berbasis Html-5, dimana materi pembelajaran pada saat tatap muka dapat lebih leluasa diakses untuk dipelajari dan diperdalam lagi dimanapun. kapanpun dan sesering mungkin peserta didik berada dan memiliki waktu luang. Fungsi dan manfaat media secara umum pada kelas eksperimen lebih banyak dan lebih ternikmati oleh peserta didik dibandingkan pada kelas kontrol. Materi pada system saraf yang abstrak seperti mekanisme pengantaran impuls, jalannya impuls yang harus melewati sinapsis, dapat lebih konkrit melalui tayangan video yang dapat diakses sesering mungkin oleh peserta didik melalui mobile learning. Demikian juga aktifitas pembelajaran dan keterlibatan alat indera para peserta didik lebih optimal. Proses membaca, melihat, mengamati dan mendengar bisa lebih sering dan lebih lama sehingga menurut pendapat peneliti berdampak pada pemrosesaan informasi yang lebih cepat dan penyimpanan pengetahuan dalam memori jangka pendek maupun memori panjang lebih mudah. Akses untuk mempelajari kajian materi pembelajaran system saraf yang lebih leluasa, memungkinkan peserta didik relatif lebih cepat mengontruksi pengetahuannya sendiri melalui mobile learning. Kelebihan penggunaan mobile learning yang dapat diakses kapan dan dimanapun ini terbukti dalam hasil penilaian pada kelompok eksperimen, jumlah peserta didik yang mendapakan nilai tuntas dalam pembelajaran system saraf lebih banyak dibandingkan dengan jumlah peserta didik yang tuntas pada kelompok kontrol dan hasil belajar kognitif peserta didik meningkat secara signifikan dibandingkan dengan kelompok kontrol. Oleh karena itu, dari hasil uji perbedaan jelas terdapat terdapat perbedaan peningkatan hasil belajar kognitif, antara kelas eksperimen dan kelas kontrol pada taraf kepercayaan $5 \%$.

Mengenai kemandirian belajar peserta didik, dari data angket hasil penelitian pada kelompok eksperimen diperoleh bahwa pada kemandirian belajar peserta didik kelompok eksperimen pada awal pembelajaran pada umumnya tergolong kategori sedang yaitu sebanyak $89 \%$, tergolong katagori tinggi $9 \%$ dan katagori rendah 3\%. Setelah pembelajaran dilakukan, maka peserta didik memiliki kemandirian belajar lebih dari setengahnya tergolong tinggi, yaitu 57\%. Katagori sedang $43 \%$ dan tidak terdapat katagori rendah.

Hamalik (Arsyad, 2016 : 19) mengemukakan bahwa 'pemakaian media pembelajaran dalam proses belajar mengajar dapat membangkitkan keinginan dan minat baru, membangkitkan motivasi dan rangsangan kegiatan belajar dan bahkan membawa pengaruh psikologis terhadap siswa'. Jadi penggunaan mobile learning berbasis Html-5 dalam proses pembelajaran system saraf merangsang aktivitas berpikir peserta didik sehingga meningkatkan kemandirian peserta didik.

Dalam Teori E-learning, kesepakatan dalam pengelompokkan teori jarak jauh seperti yang dikemukakan Keegan (Darmawan, 2016:53), diantaranya tentang a). Teori kemandirian dan Otonomi, pendidikan jarak jauh berpotensi menciptakan kemandirian dan otonomi, karena sifatnya yang menawarkan pilihan belajar, sehingga potensi dan kapasitas belajar berkembang secara individual. b). Teori Self-Regulated Learning, teori ini menekankan pentingnya pengaturan diri 
dalam mengikuti program pembelajaran. Lidden dan Harris (Darmawan, 2016:53)), mengidentifikasi enam ukuran selfregulated learning yaitu epistemological beliefs, suatu pemahaman sendiri seseorang dari system pengetahuannya. Motivation, keinginan belajar atau pencapaian belajar yang lebih baik yang datang dari motivasi internal maupun eksternal.Metacognition, pengetahuan tentang kognisi dan kesadaran pemikiran dan pembelajarannnya sendiri. Learning strategi, starategi peserta didik yang tahu dan dapat memanfaatkan pembelajaran. Contextual sensitivity, kemampuan untuk memahami situasi permbelajaran tertentu dan bagaimana mengidentifikasi suatu masalah dan memecahkannya. Environmental utilization/control, menggunakan sumbersumber eksternal untuk mancapai solusi.

Kemandirian belajar peserta didik pada kelompok eksperimen dan kelompok kontrol sudah teramati sejak sebelum melakukan proses pembelajaran melalui angket kemandirian belajar dan lembar observasi kemandiriaan belajar. Dari hasil angket kelompok eksperimen, mempunyai nilai rata-rata rank sebesar 47,84; sedangkan untuk kelompok kontrol mempunyai rata-rata rank sebesar 20,35. Kemudian nilai Mann-Whitney sebesar 110,5 dengan $\mathrm{z}$ sebesar $-5,736$ dan nilai Asymp. Sig. (2-tailed) sebesar 0,000. Adapun kriteria pengujian hipotesis adalah jika nilai Asymp.Sig. (2-tailed) lebih besar dari $\alpha$, maka Ho diterima. Karena nilai Asymp. Sig. (2-tailed) lebih kecil dari $\alpha$, maka hasil pengujian tersebut menerima Ha dan menolak Ho, sehingga dapat disimpulkan bahwa: "Terdapat perbedaan peningkatan kemandirian belajar, antara kelas eksperimen dan kelas kontrol setelah".

Sedangkan dari hasil obesrvasi kemandirian belajar peserta didik kelompok eksperimen pada pertemuan pertama yaitu $79,17 \%$ lebih tinggi dibandingkan dengan kemandirian belajar pada kelompok kontrol yaitu 70,00\%. Demikian pula hasil observasi pada proses pembelajaran pertemuan kedua terdapat peningkatan dari kedua kelompok. Kemandirian belajar peserta didik kelompok eksperimen pada pertemuan kedua yaitu $89,17 \%$ lebh tinggi dibandingkan dengan kemandirian belajar pada kelompok kontrol yaitu 80,83\%. Kemandirian belajar yang teramati pada kelompok eksperimen lebih tinggi baik pada pertemun pertama maupun pada pertemuan kedua dibandingkan dengan kelompok kontrol. Indikator-indikator kemandirian belajar pada lembar observasi semua terpenuhi oleh peserta didik pada kedua kelompok. Kedua kelompok menunjukkan bersikap percaya diri, mampu tidak tergantung pada orang lain, bersikap berani dalam mengambil keputusan, mampu mengatasi atau memecahkan masalah sendiri, bertindak kreatif berani mencoba hal baru, mampu dan berani dalam menyampaikan pendapat. Tetapi skor penilaian pada indikatorindikator kemandirian berbeda antara kelompok eksperimen dan kelompok kontrol. Hal ini dimungkinkan karena ada indikator-indikator kemandirian belajar baik pada angket ataupun lembar observasi tidak terfasilitasi diantaranya oleh dukungan media pembelajaran. Pada kelompok eksperimen kemandirian lebih berkembang karena terstimulasi dan terlatih oleh fasilitas mobile learning berbasis Html-5, dimana peserta didik dapat mengakases lebih leluasa dimana dan kapanpun di luar proses pembelajaran tatap muka. Seperti yang dikemukakan oleh Darmawan (2016:24), bahwa pembelajaran multimedia mobile tidak hanya dapat dilakukan di ruang kelas secara fisik tetapi konten pembelajaran dapat dibawa keluar kelas.

Kesempatan pengalaman belajar yang diberikan pada kelompok eksperimen dapat meningkatan kemandrian belajar, peserta didik lebih mampu mengerjakan tugas tanpa tergantung pada orang lain, karena 
dapat melihat kembali materi pada mobile learning berbasis Html-5, lebih banyak kesempatan untuk mengulang pembahasan pembelajaran biologi pada waktu luang. Dan ini merupakan salah satu kelebihan mobile learning dibandingkan dengan pembelajaran lain yaitu dapat digunakan dimana-pun pada waktu kapan-pun.

Sedangkan pada kelompok kontrol dengan pembelajaran biasa yang tidak menggunakan mobile learning berbasis Html-5 peserta didik tidak memiliki akses yang lebih leluasa mengulang pembelajaran dimana dan kapanpun, sehingga kemandiriannya kurang optimal berkembang dibanding dengan kelompok eksperiman karena kurang terlatih dengan stimulus pengalaman belajar yang di berikan.

\section{E. SIMPULAN DAN REKONENDASI}

Berdasarkan rumusan masalah, hasil penelitian, dan pembahasan yang telah dilakukan, maka peneliti menyimpulkan bahwa peningkatan hasil belajar kognitif kelas eksperimen yaitu kelas yang dalam proses pembelajarannya menggunakan mobile learning berbasis Html-5 menunjukkan peningkatan katagori tinggi dan kategori sedang. Sedangkan peningkatan hasil belajar kognitif kelas kontrol yaitu yang dalam proses pembelajarannya tidak menggunakan mobile learning berbasis $\mathrm{Html}$ menunjukkan peningkatan katagori tinggi, sedang, dan rendah. Terdapat perbedaan peningkatan hasil belajar kognitif, antara kelas eksperimen dan kelas kontrol.

Untuk kemandirian belajar, peningkatan kemandirian belajar peserta didik kelas eksperimen yaitu yang dalam proses pembelajarannya menggunakan mobile learning berbasis Html-5, menunjukkkan peningkatan yang rendah dan sedang, serta tidak ada yang mengalami peningkatan yang tergolong tinggi. Sedangkan peningkatan kemandirian belajar kelas kontrol yaitu yang dalam proses pembelajarannya tidak menggunakan mobile learning berbasis Html-5 mengalami peningkatan katagori rendah dan sedang. serta tidak ada yang mengalami peningkatan yang tergolong tinggi. Kemandirian belajar peserta didik pada kelompok eksperimen dan kelompok kontrol tidak menunjukkan peningkatan dengan katagori tinggi, tetapi terdapat perbedaan peningkatan kemandirian belajar, antara kelas eksperimen dan kelas kontrol.

\section{Rekomendasi}

Berdasarkan hasil penelitian dan kesimpulan, mengenai penggunaan Mobile learning berbasis HTML-5 dalam proses pembelajaran biologi dapat meningkatkan hasil belajar kognitif dan kemandirian belajar peserta didik. Oleh karena itu hendaknya lembaga penyelenggara pendidikan terkait memberi kebijakan yang lebih luas untuk terselenggaranya proses pembelajaran yang berbasis TIK, memberi dukungan sarana dan prasarana yang diperlukan dan tidak membuat kebijakan melarang peserta didik untuk membawa smartphone ke sekolah. Dari peneliti ini merekomendasaikan bahwa selanjutnya penelitian lebih dikembangkan untuk mencari keterkaitan antara penggunaan mobile learning dengan peningkatan kemandirian belajar, lebih dikembangkan untuk model pembelajaran yang lain seperti model pembelajaran berbasis masalah., dan sdikembangkan untuk lebih menguatkan fungsi multimedia sebagai sebagai suplement (tambahan) yang sifatnya pilihan (opsional), pelengkap (komplemen), atau pengganti (substitusi).

\section{F. REFERENSI}

Abdulhak, I dan Darmawan, D. ( 2013). Teknologi Pendidikan.(Cetakan pertama) PT. Remaja Rosdakarya.

Ali, M dan Asrori, M. (2018). Psikologi Remaja Perkembangan Peserta Didik. 
(cetakan ketiga belas). Jakarta : PT Bumi Aksara.

Arsyad, A. (2016). Media Pembelajaran (edisi revisi.cetakan ke-19 Jakarta : PT. Raja Grafindo Persada.

Darmawan, D. (2014). Inovasi Pendidikan. (cetakan ketiga) PT Remaja Rosdakarya.

Darmawan, D. (2016). Pengembangan Elearning Teori dan Desain. (cetakan kedua) Bandung : PT Remaja Rosdakarya.

Darmawan, D. (2016). Mobile Lerning. (cetakan kesatu) Jakarta : PT. Raja Grafindo Persada.

Darmawan, D. (2016). Metode Penelitian Kuantitatif. (cetakan ketiga) Bandung : PT Remaja Rosdakarya.

Darmawan, D. (2017). Teknologi Pembelajaran. (cetakan kelima) Bandung: PT Remaja Rosdakarya.

Daryanto. (2013). Inovasi Pembelajaran Efektif. (cetakan I) Bandung : Penerbit Yrama Widia.

Hamalik, O. (2016). Proses Belajar Mengajar. (cetakan kedelapan belas) Jakarta : PT Bumi Aksara.

Jihad, A dan Haris, A. (2013). Evaluasi Pembelajaran. Yogyakarta: Multi Pressindo.
Joyce,B, et.al.(2009). Model of Teaching (eighth edition). Model-Model Pengajaran (cetakan 1).Yogyakarta: Pustaka Pelajar.

Mujiman, H. (2011). Belajar Mandiri. (cetakan ketiga) Yogyakarta: Pustaka Pelajar.

Munir, (2015). Multimedia Konsep dan Aplikasi dalam Pendidikan. (cetakan ketiga) Bandung : Alfabeta.

Sarrab, M , et.al.(2012) "Mobile Learning (M-Learning) And Educational Environments", International Journasl of Distributed and Parallel Systems (IJDPS) (.3), No.4.

Sugiyono. (2013). Metode Penelitian Kuantitatif, Kualitatif dan R 7D. Bandung: Penerbit alfabeta.

Sujana, N. (2013). Cetakan ketigabelas) Bandung : Sinar Baru Algensindo.

Sumarmo,U (2016) ." Kemandirian Belajar: Apa, Mengapa, Dan Bagaimana Dikembangkan Pada Peserta Didik" . FPMIPA UPI.

Surya, M. (2016). Strategi Kognitif Dalam Pembelajaran. (cetakan kedua) Bandung: Alfabeta.

Surya, M. (2015). Psikologi Gur Konsep dan aplikasi dari Guru untuk Guru. (Cetakan ketiga). Bandung: Alfabeta. 